\title{
Using Nested Logit Model in the Study of Proxy Contest
}

\author{
Maggie Foley ${ }^{1}$, Chengru Hu${ }^{2}$, Fabrizioi Rossi ${ }^{3}$, Richard Cebula ${ }^{1}$ \\ ${ }^{1}$ Davis College of Business, Jacksonville University, Jacksonville, FL, USA \\ ${ }^{2}$ School of Business and Liberal Arts, SUNY Canton, Canton, NY, USA \\ ${ }^{3}$ University of Cassino and Southern Lazio (Italy), Frosinone, Italy \\ Email:mfoley3@ju.edu,hu@canton.edu,f.rossi@unicas.it, rcebula@ju.edu
}

How to cite this paper: Foley, M., Hu, C.R., Rossi, F. and Cebula, R. (2019) Using Nested Logit Model in the Study of Proxy Contest. Journal of Mathematical Finance, 9, 202-227.

https://doi.org/10.4236/jmf.2019.92011

Received: December 8, 2018

Accepted: May 24, 2019

Published: May 27, 2019

Copyright ( 2019 by author(s) and Scientific Research Publishing Inc. This work is licensed under the Creative Commons Attribution International License (CC BY 4.0).

http://creativecommons.org/licenses/by/4.0/

\begin{abstract}
The nested logit model has been extensively used in studies focused on transportation. This model is based on a choice modeling framework and is also applicable to the study of a proxy contest. In this study, we illustrate how the nested logit model can be effectively used to evaluate a case of a proxy contest. We also present the specific model that can be used to predict the possibility of the occurrence of proxy contests.
\end{abstract}

\section{Keywords}

Nested Logit Model, Proxy Contest, Choice Modeling

\section{Introduction}

The nested logit model has been commonly used in various studies of transportation and commercial behaviors ([1] [2]). The nested logit model is specifically based on a "choice" modeling framework. It considers human beings as highly rational as we tend to make the best choices that we think has more value in terms of utility. From this perspective, when faced with the assessing the utility function of different choices, the respondents are observed to make the choices that best suit their needs. Considering the expected value of the available choices, with the logit model, the optimum probability for each choice can be evaluated.

For studies in finance, the use of the nested logit model as a statistical tool is not very common. But there are several circumstances in which the nested logit model can be involved in finance because of the need to make choices regarding money/cash holdings and expenditures, which is a common situation in the financial world.

In this study, we illustrate how to build the nested logit model using the proxy 
contest as the framework. From a theoretical point of view, the person who controls the board has an absolute authority over the entire firm. This can be achieved by shareholder activists, who will leverage on the proxy contest to achieve this. There will be a formidable resistance in a situation where the firm is publicly traded, having as many as many as ten or more board members. In the corporate world, there is no shortcut to getting a board seat. As a candidate vying for a board seat, one would have to win the support of a sufficient number of shareholders (a majority) during the annual shareholder meeting in order to get a board seat over time. The shareholder population is a widely dispersed one; this means that a candidate would need to use undertake a convincing campaign to win the needed votes during an election. This can be a very expensive plan to execute. For larger firms, the total expenses incurred from an election process can reach as high as $\$ 1$ million and about $\$ 100,000$ for smaller firms. On the average, the candidate should expect expenses anywhere between $\$ 200,000$ and $\$ 1$ million ([3] [4]). A good example of a proxy test contest was the case between Sam Wyly and Computer Associates Inc. As reported in the Los Angeles Times, the tussle for victory cost both contenders as much as $\$ 20$ million each. In the end, the management team of Computer Associates Inc. emerged as the winner. Proxy contests are a rather unlikely choice for many investors because of the high-cost implications. Many stakeholders have found alternatives to the expensive proxy contests as ways to prevent any potential uprising that could lead to a takeover of the company. A good example is a situation where in a staggered board restricts one-third of the board seats to be reelected every year; hence, it might take as long as three years before activists could potentially replace the entire board.

Shareholder activists can achieve an early end for a proxy contest before the annual shareholders meeting when shareholders come together to vote for the next set of board representatives. Once the shareholder activist makes a public announcement indicating the intention of shareholders to initiate a proxy fight at some time in the future, the start of a proxy contest is initiated. The end of a proxy contest is not concluded until the two parties have reached agreement in private and have amicably settled the disputes. Settlements can be made when the representative activist shareholder is invited to become a board member. In a situation where it is not possible to arrive at an agreement, the proxy contest would proceed to the next stage where the shareholder activist would make public declarations that the two parties have irresolvable disputes at this stage, the proxy contest will become a fierce tussle for authority. Even at this stage of the proxy contest, when the SEC has been notified of the disputes, it is still possible for the two parties to arrive at a private agreement before the annual shareholders meeting. The finalization of the negotiations signifies the end of a proxy contest. If the negotiations fail, then the final resolution will be undertaken at the annual shareholder meeting, when the shareholders will be expected to vote. The new board members would be announced to the public, and the winning 
party will publicly declare its victory (either management or the shareholder activists).

In summary, the entire process of a proxy contest can be broken down into three stages, with the end of each stage either resulting in an agreement or with the parties involved proceeding to the next stage. This is why a three-stage nested logit model is the most suitable statistical tool for the study of a proxy contest.

The remainder of the study is organized as follows. Section 2 provides the review of proxy contest and introduces the model. Section 3 describes the model assumptions and specification. Section 4 reveals the empirical results using nested logit model. Section 5 provides conclusions from the study.

\section{The Proxy Contest and Setting up the Model}

The responsibilities of a board seat involve fiduciary duties. In many cases, proxy contests have been used by the shareholder activists to get one of their members elected to the board. The shareholder activists launch campaigns aimed at securing top positions in the firms targeted. They typically accuse the firm's management of making wrong decisions with regard to the firms' current and future plans, their methods of overseeing the firm's operations and often express a variety of other criticisms. The shareholder activists propagate inciting messages to the stockholders, informing them of the damage the management team is causing to the firm, which will potentially reduce the value of their stock. The end of a campaign like this is usually a tough proxy fight. From the management's perspective, the shareholder activists seek to disrupt the activities' of the firm in a selfish bid to strengthen their positions against the management. For every dispute between the two parties, there is always room for an amicable agreement to be arrived at. The management can acknowledge and implement the suggestions of the activists, and they can also choose to appoint activists to become a board member.

From a general viewpoint, the following figure could be used to illustrate the processes through which a proxy contest can be escalated:

The first offensive used by the activists at the beginning of a proxy contest is the propagation of a media-based threat against the company or companies with which they have disputes. It is very common to experience dissatisfaction from shareholders when the company is performing poorly or if the agency costs are very high. Firms that fall into this category will most likely be targeted. Also, shareholders can express their grievances by making shareholder proposals to address the issues ([5] [6] [7]).

The management of a firm can quickly address any issues highlighted in the media accusations to prevent the case for escalating. From our studies, only half of the known proxy contests were ended at the first stage. The rest cases proceeded to the second stage during which the SEC was notified by the activists of their plans to push for a proxy fight. 
Firms that fail to prevent moves for a proxy fight will appear vulnerable at this stage. This implies that the top management team will potentially lose their positions at the helm of affairs. Faced with this threat, a proxy contest could be averted if the management team gives in to the requests of the shareholder activists. If this happens, the shareholders can either back down from a proxy contest or choose to proceed with an election. This is the final stage of a proxy contest.

In summary, shareholder activists become aggravated by firms with huge potential for growth which will benefit the shareholder but performing poorly due to poor management. These firms may be targeted for a proxy contest, which will often start with the launch of a media accusation. The shareholder activists announce their decision to proceed with a proxy contest with the firms' management in the media. The firms that make the best targets are the one that has made few or no provisions to prevent or frustrate a takeover. These firms run with an independent board who are not deeply involved in decision making hence they can be swayed by external influence. The impact of a media threat can cause the management to begin negotiations with the activists which can end the proxy contest when an amicable agreement is reached. Failure to come to an agreement will propel the activists to proceed with informing the SEC of its plans. Even at this stage, agreements can still be arrived before the annual shareholder meeting when a vote will be held. Firms that are usually targeted by the shareholder activists are those firms that have a larger percentage of external supporters than internal supporters.

From the analysis above, an ideal nested structure in three distinctive levels clearly reveals the provisions for a proxy contest. This is illustrated in Figure 1. Specifically, firms at the lower levels have certain firm characteristics which are similar to those firms at the upper levels due to the nested structure representing the data. An example is a move by the shareholder activists against poorly performing firms by propagating media threats. This means firms involved in proxy contests that progress to the stage where the SEC is notified are poorly performing firms. This eliminates the assessment of performance for firms when a SEC filing has been made because they had already been targeted by the media threat at the initial stage of the proxy contest due to poor performance. This generalizes poor performance as a factor that affects both the firms at the upper and lower levels. In view of this, firm attributes included in the upper levels should be shared by firms in the lower levels and there should be different considerations for the different stages of a proxy contest.

\section{Using Nested Logit Model}

\subsection{Assumption of the Nested Logit Model}

As a result of the structure illustrated in Figure 1, the nested logit model is adopted in this study. The model requires loads of the assumptions explained below.

First, the nested logit model is applicable under the assumption that the various alternatives could be separated into nests. From Figure 1, the nested 


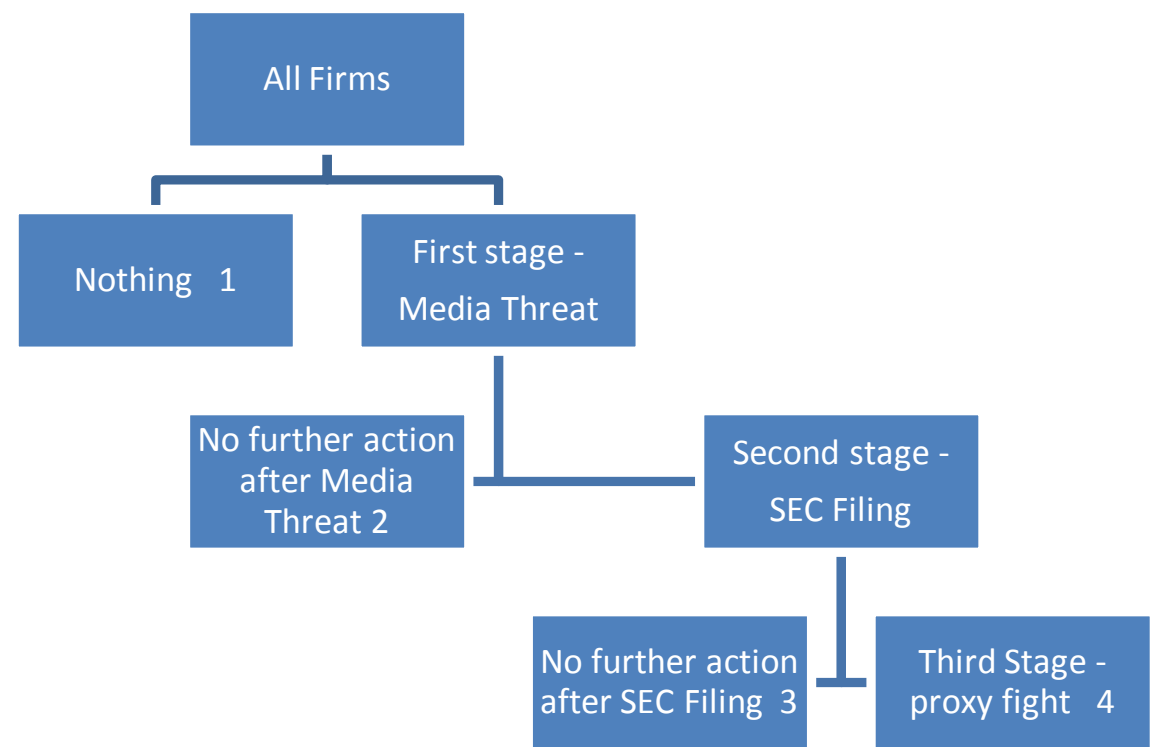

Figure 1. Development of a proxy contest (Nested Tree Structure).

structure for the proxy contests is compellingly demonstrated. This means the assumptions have been convincingly satisfied in this study.

Second, the nested logit model relaxes assumption of Independent \& Identically Distributed (IID) and recognizes the possibility that each alternative may have information in the unobserved influences of that alternative, which in turn has a role to play in determining an outcome that is different across the alternative branches ([8]). This difference implies that the variances of error might be different but the information content could be similar among subsets of alternatives generating some amount of correlation among these subsets ([8]). Under the context of the proxy contests, IID indeed does not hold. In fact, the utilities of the third and the fourth outcome are highly correlated in that the occurrence of both events depends on the contingency of the SEC Filing.

Lastly, the application of a nested logit model relaxes the restriction that the choice between any two pairs of alternatives is simply a binary logit model ([9]). In other words, this Independence of Irrelevant Alternatives (IIA) can be too restrictive under the nested logit model. Indeed, if the 'No further action after a Media Threat' in Figure 1 is not an option anymore, then more cases of the 'No further action after SEC Filing' will occur. This will change the ratio of the occurrence of the two mutually exclusive alternatives nested with SEC Filing. It should be noted that if the IIA is not applicable, then it can be assumed that IID will not be applicable because the IIA is a consequence of the assumption that the errors are IID ([2] [10]).

In accordance with the standard procedure, we test the assumption of IIA by applying the Hausman ([11]) specification test to re-estimate the model on a subset of the alternatives since this test is not sensitive to the tree structure that we specify for a nested logit model ([2] [10]). Hence, if IIA is valid, there will be a minimal difference between the parameters arrived at for the subset of alterna- 
tives and those ones obtained on the full set of alternatives. Where the difference is seen to be significant, the assumption of IIA will not be applicable. The test of the IIA assumption is provided in Section 4.

\subsection{Specifications of the Nested Logit Model}

The basic nested logit model is dependent on a "choice" modeling framework. It is based on the fact that people act rationally to make choices among options that have the highest utility values to them. This indicates that for a utility function for the different choices, respondents would be expected to make the optimum choice. This will depend on the estimated utility value expected from the available choices, as obtainable from the logit model. An attempt to the optimum probability for the various choices will be possible.

$$
\pi_{\text {choice }, i}=\frac{\mathrm{e}^{\text {utility }, i}}{\sum_{i=1}^{n} \mathrm{e}^{\text {utility }, i}}
$$

where $i$ represents the $i^{\text {th }}$ choice among $n$ alternatives.

A complicated choice structure of decision making could lead to the structure being nested in many layers. For each layer, it is possible to estimate the probability for the different choices using the equation above, with the exception of the calculated probability for the choice which will be a conditional probability. The choice i's marginal probability has a value equal to the conditional probability multiplied by the marginal probability of the previous event which is affiliated with the choice $i$. This means it is possible to get a marginal probability function for the various alternatives. With a known choice, it is possible to get the log likelihood function.

$$
\ln L=\ln \sum_{i=1}^{n}\left(\pi_{\text {choice }, i} \times \text { occurrence }_{\text {choice }, i}\right)
$$

where $i$ represents the $i^{\text {th }}$ choice among $n$ alternatives.

With reference to Figure 1, while Nothing represents the independent (degenerate branch) alternative, there is a hierarchy that establishes groupings as Media Threat with two distinct branches: 'No further action after Media Threat' and SEC Filing. Proceeding to the next level, 'No further action after Media Threat' presents an independent alternative, whereas SEC Filing is connected with two distinct alternatives: No further action after SEC Filing and a proxy fight.

Figure 2 shows the three level nested tree structure representing the different states of proxy contests. There are the four elemental alternatives: Nothing, No further action after Media Threat, No further action after SEC filing and the proxy fight.

Figure 2 shows the marginal outcomes in the limb level. This is the outcome indicating Nothing and Media Threat state. There are two basic conditional outcomes. One of them is either the case of a probability of a SEC filing state or the case of a No further action after Media Threat, which is conditional even though the firm is classified under the Media Threat. The second conditional 


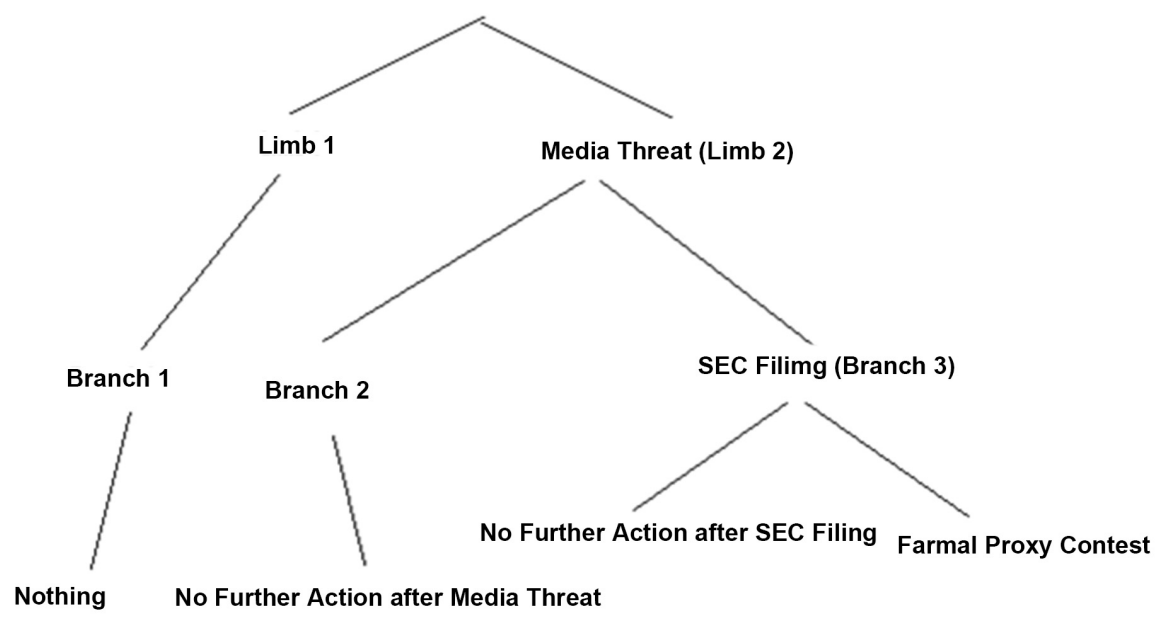

Figure 2. Nested tree structure for states of proxy contests.

outcome is the probability of a "No further action after SEC filing" or a proxy fight; this will be conditional depending on if the firm is classified under the SEC filing category. However, there are three nodes, Limb 1, Branch 1 and Branch 2; these three nodes are subject to degeneration with a single extension.

In summary, the nested logit models begin with the calculation of the expected utilities for the lower level and the utilities at the higher levels which include the expected utilities from the lower levels. This relies on the expected utilities achievable at the different levels. The maximum likelihood function (ML function) is equal to the log of the summation for the different utilities multiplied by the corresponding proxy contest results (indicator variable). This ML function is concave and it is characterized by efficient and consistent solutions.

The utility models at each level are, as follows:

$$
\begin{aligned}
\text { Utility }_{\text {Media Threat }}= & \gamma_{(1)}\left[\beta_{1(1)} \times \text { Free Cash Flow }+\beta_{2(1)} \times\right. \text { Leverage } \\
& +\beta_{3(1)} \times \text { Market to book ratio }+\beta_{4(1)} \times \text { Stock Returns } \\
& +\beta_{5(1)} \times \text { Firm Size }+\beta_{6(1)} \times \text { Prior Shareholder Proposals } \\
& \left.+1 / \lambda(1,1) \times \mathrm{IV}_{(1)}\right]
\end{aligned}
$$

where,

$$
\begin{aligned}
& \operatorname{IV}_{(1)}=\ln \left(e^{\lambda(1,1) \text { utility of SEC Filing }}+e^{\lambda(2,1) \text { utility of No further actions after Media Threat }}\right) \\
& \begin{aligned}
\text { Utility }_{\text {SEC Filing }}= & \lambda_{(1,1)}\left[\beta_{1(1,1)} \times \text { Poison pills }+\beta_{2(1,1)} \times\right. \text { Staggered Boards } \\
& +\beta_{3(1,1)} \times \text { Merger }+\beta_{4(1,1)} \times \text { Bylaw }+\beta_{5(1,1)} \times \text { Charter } \\
& +\beta_{6(1,1)} \times \text { Board Independence Level }+\mathrm{IV}_{(1,1)}
\end{aligned}
\end{aligned}
$$

where,

$$
\begin{aligned}
\operatorname{IV}_{(1,1)}=\ln & \left(e^{(\text {utility of proxy fight })}+e^{(\text {utility of No further actions after SEC Filing })}\right) \\
\text { Utility }_{\text {proxy fight }}= & \beta_{1 a} \times \text { Insider ownership }+\beta_{2 a} \times \text { Block-olders' Ownership } \\
& +\beta_{3 a} \times \text { Institutional ownership }+\beta_{4 a} \times \text { No of funds } \\
& +\beta_{5 a} \times \text { active block-holders }
\end{aligned}
$$




\subsection{The Application of the Nested Logit Model in the Study of Proxy Fight}

This section will cover the reports for the theoretical analysis of the nested logit model in the context of the proxy contests. For this study, the choice behavior is described by applying a random utility framework. Also, the alternative chosen should provide the highest utility.

According to Hensher, Rose, and Greene ([12]), the scale parameters for the different limbs, branch and elemental alternatives for the three nested structure above is illustrated as follows:

Limb: $\gamma(i)$

Branch: $\lambda(j, i)$

Elemental Alternative: $\mu(j, \hat{i})$ where:

$\gamma(i)$ is the scale parameter for the $i^{\text {th }}$ limb, $\lambda(j, i)$ is the scale parameter for the $j^{\text {th }}$ branch of limb $i$. Then, $\mu(j, i)$ represents the scale parameter for the elemental alternatives of branch $j$ and limb $i$. It is identical for each alternative present within any given branch, because the variance of each elemental alternative present within branch $j$ is equal.

The utility functions in the higher levels also include IV (inclusive value) which is calculated as the natural logarithm of the sum of the exponentials of the utility expressions for the level directly below which the IV is calculated.

For simplicity of model presentation, we normalize on $\mu(j, i)$ following random utility model 1 (RU 1).

Level 1 (elemental alternatives):

As discussed in Section 2, we focus on variables describing shareholder structures for the bottom level:

1) Aggregated ownership by insiders.

2) Aggregated ownership by block-holders.

3) Aggregated ownership by institutional investors.

4) Number of institutional funds.

5) The indicator variable for filing of schedule 13-d.

For the elemental alternatives at Level 1 , the utility functions can be expressed as follows.

$$
\begin{aligned}
& \quad V_{\text {proxy fight }}=V_{a} \\
& =\mu_{1} \beta_{1 a} f\left(X_{1 a}\right)+\mu_{1} \beta_{2 a} f\left(X_{2 a}\right)+\mu_{1} \beta_{3 a} f\left(X_{3 a}\right) \\
& \quad+\mu_{1} \beta_{4 a} f\left(X_{4 a}\right)+\mu_{1} \beta_{5 a} f\left(X_{5 a}\right) \\
& V_{\text {No further actions after SEC filing }}=V_{b} \\
& =\beta_{0 b}+\mu_{2} \beta_{1 b} f\left(X_{1 a}\right)+\mu_{2} \beta_{2 b} f\left(X_{2 b}\right)+\mu_{2} \beta_{3 b} f\left(X_{3 b}\right) \\
& \quad+\mu_{2} \beta_{4 b} f\left(X_{4 b}\right)+\mu_{2} \beta_{5 b} f\left(X_{5 b}\right)
\end{aligned}
$$

For No further actions after Media Threat and Nothing, utilities are defined at the higher level, not at the bottom level. As such, no attributes are included in the utility function at this level. Hence, it follows that: 


$$
\begin{gathered}
V_{\text {No further actions after Media Threat }}=V_{c}=0 \\
V_{\text {nothing }}=V_{d}=0
\end{gathered}
$$

Using RU $1^{1}$ as suggested by Hensher, Ross and Greene (2005), we normalize $\mu_{1}=\mu_{2}=1$, hence,

$$
\begin{gathered}
V_{a}=\beta_{1 a} f\left(X_{1 a}\right)+\beta_{2 a} f\left(X_{2 a}\right)+\beta_{3 a} f\left(X_{3 a}\right)+\beta_{4 a} f\left(X_{4 a}\right)+\beta_{5 a} f\left(X_{5 a}\right) \\
V_{b}=\beta_{1 b} f\left(X_{1 a}\right)+\beta_{2 b} f\left(X_{2 b}\right)+\beta_{3 b} f\left(X_{3 b}\right)+\beta_{4 b} f\left(X_{4 b}\right)+\beta_{5 b} f\left(X_{5 b}\right) \\
V_{c}=0 \\
V_{d}=0
\end{gathered}
$$

Since No further actions after SEC Filing and proxy fight are nested under the branch of SEC Filing, the probabilities of the two alternatives are defined as follows:

$$
\begin{aligned}
\pi & (a, \text { proxy fight })=\frac{e^{V_{a}}}{e^{V_{a}}+e^{V_{b}}} \\
= & e^{\wedge}\left(\beta_{1 a} f\left(X_{1 a}\right)+\beta_{2 a} f\left(X_{2 a}\right)+\beta_{3 a} f\left(X_{3 a}\right)+\beta_{4 a} f\left(X_{4 a}\right)\right. \\
& \left.+\beta_{5 a} f\left(X_{5 a}\right)\right) /\left(e ^ { \wedge } \left(\beta_{1 a} f\left(X_{1 a}\right)+\beta_{2 a} f\left(X_{2 a}\right)+\beta_{3 a} f\left(X_{3 a}\right)\right.\right. \\
& +\beta_{4 a} f\left(X_{4 a}\right)+\beta_{5 a} f\left(X_{5 a}\right)+e^{\wedge}\left(\beta_{1 b} f\left(X_{1 a}\right)+\beta_{2 b} f\left(X_{2 b}\right)\right. \\
& \left.+\beta_{3 b} f\left(X_{3 b}\right)+\beta_{4 b} f\left(X_{4 b}\right)+\beta_{5 b} f\left(X_{5 b}\right)\right) \\
\pi & (b, \text { No further actions after SEC Filing })=\frac{e^{V_{b}}}{e^{V_{a}}+e^{V_{b}}} \\
= & e^{\wedge}\left(\beta_{1 b} f\left(X_{1 a}\right)+\beta_{2 b} f\left(X_{2 b}\right)+\beta_{3 b} f\left(X_{3 b}\right)+\beta_{4 b} f\left(X_{4 b}\right)\right. \\
& \left.+\beta_{5 b} f\left(X_{5 b}\right)\right) /\left(e ^ { \wedge } \left(\beta_{1 a} f\left(X_{1 a}\right)+\beta_{2 a} f\left(X_{2 a}\right)+\beta_{3 a} f\left(X_{3 a}\right)\right.\right. \\
& \left.+\beta_{4 a} f\left(X_{4 a}\right)+\beta_{5 a} f\left(X_{5 a}\right)\right)+e^{\wedge}\left(\beta_{1 b} f\left(X_{1 a}\right)+\beta_{2 b} f\left(X_{2 b}\right)\right. \\
& \left.\left.+\beta_{3 b} f\left(X_{3 b}\right)+\beta_{4 b} f\left(X_{4 b}\right)+\beta_{5 b} f\left(X_{5 b}\right)\right)\right)
\end{aligned}
$$

Nothing and No further actions after Media Threat are obviously degenerative alternatives. Nothing is not partitioned within a branch or a limb. Hence, Probability $(d$, nothing $)=e^{V_{d}} / e^{V_{d}}=1$. This implies that the probability that Nothing will be chosen is not calculated at Level 1, but rather is calculated at Level 3, the highest level of the tree structure being explored. In comparison, No further actions after Media Threat is partitioned within the branch of Media Threat. Still, Probability $(c$, No further actions after Media Threat $)=e^{V_{c}} / e^{V_{c}}=1$. However, this probability is calculated at Level 2 rather than Level 1.

Level 2 (Branch):

We focus on antitakeover measures and board composition for the branch level, namely:

1) Poison pills position.

2) Staggered board position.

3) Super majority requirement on merger.

${ }^{1}$ In the RU 1 model the scale parameters are normalized at the bottom of the tree, in contrast to the RU 2 model where the scale parameters are normalized at the branch level. 
4) Super majority requirement on charter.

5) Super majority requirement on bylaw.

6) Board independent measure.

Level 2 consists of three branches. Branch 2, No further actions after Media Threat and Branch 3, SEC Filing, stem from Limb 2, Media Threat. Branch 1 is degenerate with only one choice at Level 2.

The utility of Branch 3 can be expressed as follows.

$$
\begin{aligned}
\mathrm{V}_{\text {SEC filing }}=V_{(1,1)}=\lambda_{1,1} & {\left[\beta_{1(1,1)} f\left(X_{1(1,1)}\right)+\beta_{2(1,1)} f\left(X_{2(1,1)}\right)+\cdots\right.} \\
& \left.+\beta_{6(1,1)} f\left(X_{6(1,1)}\right)+\left(1 / \mu_{(1,1)}\right) * \mathrm{IV}_{(1,1)}\right]
\end{aligned}
$$

where,

$$
\mathrm{IV}_{(1,1)}=\ln \left(e^{\mu(1,1) V_{a}}+e^{\mu(1,1) V_{b}}\right)
$$

Under RU1 which normalize $\mu(1,1)=\mu(2,1)=\mu(3,2)=1$, we got the following.

$$
V_{(1,1)}=\lambda_{(1,1)}\left[\beta_{1(1,1)} f\left(X_{1(1,1)}\right)+\beta_{2(1,1)} f\left(X_{2(1,1)}\right)+\cdots+\beta_{6(1,1)} f\left(X_{6(1,1)}\right)+\operatorname{IV}_{(1,1)}\right]
$$

where,

$$
\mathrm{IV}_{(1,1)}=\ln \left(e^{\mu(1,1) V_{a}}+e^{\mu(1,1) V_{b}}\right)=\ln \left(e^{V_{a}}+e^{V_{b}}\right)
$$

$V_{a}$ and $V_{b}$ are known from Level 1 .

For Branch 2, it is assumed that the utility for No further actions after Media Threat is defined at this level. Hence, the expected utilities, the IV, from Level 1 is zero.

$$
\begin{aligned}
& V_{\text {branch 2 }}=V_{(2,1)} \\
& =\lambda_{(2,1)}\left[\beta_{1(2,1)} f\left(X_{1(2,1)}\right)+\beta_{2(2,1)} f\left(X_{2(2,1)}\right)+\cdots+\beta_{6(2,1)} f\left(X_{6(2,1)}\right)+\left(\frac{1}{\mu_{(2,1)}}\right) \times \operatorname{IV}_{(2,1)}\right] \\
& =\lambda_{(2,1)}\left[\beta_{1(2,1)} f\left(X_{1(2,1)}\right)+\beta_{2(2,1)} f\left(X_{2(2,1)}\right)+\cdots+\beta_{6(2,1)} f\left(X_{6(2,1)}\right)\right]
\end{aligned}
$$

In comparison, Branch 1 linked with Nothing at Level 1 is not defined at this level, but at Level 3. Hence, $V_{\text {branch 1 }}$ or $V_{(3,2)}$ is still zero.

Next, similar to the conditional logit model, the probability that a branch is chosen is calculated only by considering other branches partitioned within the same limb.

Hence,

$$
\begin{gathered}
\pi_{(1,1)}=\frac{e^{V(1,1)}}{e^{V(1,1)}+e^{V(2,1)}} \\
\pi_{(2,1)}=\frac{e^{V(2,1)}}{e^{V(1,1)}+e^{V(2,1)}} \\
\pi_{(2,1)}=1, \text { since this branch is degenerate. }
\end{gathered}
$$


Level 3 (limb):

Stock performance, prior shareholder proposals and agency costs are the focus of Limb Level. We also control for firm size:

1) Number of shareholder proposals in the prior year.

2) Market adjusted stock returns.

3) Industry adjusted log market to book ratio.

4) Industry adjusted free cash flow.

5) Industry adjusted square root leverage ratio.

6) Industry adjusted log firm size.

There are two limbs stemming from the same trunk. The utility function of Limb 2 regarding Media Threat with two branches can be written as follows.

$$
\begin{aligned}
& V_{\text {Media Threat }}=V_{(1)} \\
& =\gamma_{(1)}\left[\beta_{1(1)} f\left(X_{1(1)}\right)+\beta_{2(1)} f\left(X_{2(1)}\right)+\cdots+\beta_{6(1)} f\left(X_{6(1)}\right)+1 / \lambda_{(1,1)} \times \mathrm{IV}_{(1)}\right]
\end{aligned}
$$

where,

$$
\mathrm{IV}_{(1)}=\ln \left(e^{\lambda(1,1) V(1,1)}+e^{\lambda(2,1) V(2,1)}\right)
$$

Under RU1, the scale parameters at Level 1 are normalized but they are free to vary at Level 2. Further, the scale parameters for each connected branch are equal since the IID assumption is maintained within each nest.

So,

$$
\lambda_{(1,1)}=\lambda_{(2,1)}=\lambda_{(1)} ; \lambda_{(3,2)}=\lambda_{(2)}
$$

Hence,

$$
V_{(1)}=\gamma_{(1)}\left[\beta_{1(1)} f\left(X_{1(1)}\right)+\beta_{2(1)} f\left(X_{2(1)}\right)+\cdots+\beta_{6(1)} f\left(X_{6(1)}\right)+1 / \lambda_{(1)} \times \mathrm{IV}_{(1)}\right]
$$

where

$$
\mathrm{IV}_{(1)}=\ln \left(e^{\lambda(1) V(1,1)}+e^{\lambda(1) V(2,1)}\right)
$$

Limb 1 is degenerate and it is assumed that the utility for Nothing is defined at this level. Hence, the expected utility, the IV, from Level 2 is zero.

$$
V_{(2)}=\gamma_{(2)}\left[\beta_{1(2)} f\left(X_{1(2)}\right)+\beta_{2(1)} f\left(X_{2(2)}\right)+\cdots+\beta_{8(1)} f\left(X_{6(2)}\right)+1 / \lambda_{(2)} \times \operatorname{IV}_{(2)}\right]
$$

Since, $\operatorname{IV}_{(2)}=0$, we get

$$
V_{(2)}=\gamma_{(2)}\left[\beta_{1(2)} f\left(X_{1(2)}\right)+\beta_{2(1)} f\left(X_{2(2)}\right)+\cdots+\beta_{6(1)} f\left(X_{8(2)}\right)\right]
$$

The probability of the first limb being selected under RU1 is as follows.

$$
\pi(1)=\frac{e^{V(1)}}{e^{V(1)}+e^{V(2)}}
$$

$$
=\frac{\gamma_{(1)}\left[\beta_{1(1)} f\left(X_{1(1)}\right)+\cdots+\beta_{6(1)} f\left(X_{6(1)}\right)+\frac{1}{\lambda_{(1)}} \times \ln \left(e^{\lambda(1) V(1,1)}+e^{\lambda(2) V(2,1)}\right)\right]}{\gamma_{(1)}\left[\beta_{1(1)} f\left(X_{1(1)}\right)+\cdots+\beta_{6(1)} f\left(X_{6(1)}\right)+\frac{1}{\lambda_{(1)}} \times \ln \left(e^{\lambda(1) V(1,1)}+e^{\lambda(2) V(2,1)}\right)\right]+\gamma_{(2)}\left[\beta_{1(2)} f\left(X_{1(2)}\right)+\beta_{2(1)} f\left(X_{2(2)}\right)+\cdots+\beta_{6(1)} f\left(X_{8(2)}\right)\right]}
$$


Similarly, for Limb 1, its probability is as follows.

$$
\pi(2)=\frac{e^{V(2)}}{e^{V(1)}+e^{V(2)}}
$$

Probability summary:

The above probabilities calculated in each level are conditional probabilities.

The following summarizes the conditional probabilities.

First, conditional on activists' choices at branch level:

$$
\begin{gathered}
\pi(a, \text { proxy fight })=\frac{e^{V_{a}}}{e^{V_{a}}+e^{V_{b}}} \\
\pi(b, \text { No further actions after SEC Filing })=\frac{e^{V_{b}}}{e^{V_{a}}+e^{V_{b}}} \\
\pi(c, \text { No further actions after Media Threat })=1 \\
\pi(d, \text { Nothing })=1
\end{gathered}
$$

Second, conditional on activists' choices at limb level:

$$
\begin{gathered}
\pi_{(1,1)}=\frac{e^{V(1,1)}}{e^{V(1,1)}+e^{V(2,1)}} \\
\pi_{(2,1)}=\frac{e^{V(2,1)}}{e^{V(1,1)}+e^{V(2,1)}} \\
\pi_{(3,2)}=1
\end{gathered}
$$

Third, conditional on activists' choices at top level:

$$
\begin{aligned}
& \pi(1)=\frac{e^{V(1)}}{e^{V(1)}+e^{V(2)}} \\
& \pi(2)=\frac{e^{V(2)}}{e^{V(1)}+e^{V(2)}}
\end{aligned}
$$

Next, the direct probabilities for each elemental alternative, each branch and each limb, can be calculated as follows.

$$
\begin{aligned}
& \pi(a, \text { proxy fight })=\frac{e^{V_{a}}}{e^{V_{a}}+e^{V_{b}}} \times \frac{e^{V(1,1)}}{e^{V(1,1)}+e^{V(2,1)}} \times \frac{e^{V(1)}}{e^{V(1)}+e^{V(2)}} \\
& \pi(b, \text { No further actions after SEC Filing }) \\
& =\frac{e^{V_{b}}}{e^{V_{a}}+e^{V_{b}}} \times \frac{e^{V(2,1)}}{e^{V(1,1)}+e^{V(2,1)}} \times \frac{e^{V(1)}}{e^{V(1)}+e^{V(2)}} \\
& \pi(c, \text { Nofurther actions after Media Threat }) \\
& =1 \times \frac{e^{V(2,1)}}{e^{V(1,1)}+e^{V(2,1)}} \times \frac{e^{V(1)}}{e^{V(1)}+e^{V(2)}} \\
& \pi(d, \text { Nothing })=1 \times 1 \times \frac{e^{V(2)}}{e^{V(1)}+e^{V(2)}} \\
& \pi(\text { Branch 3, SEC filing })=\frac{e^{V(1,1)}}{e^{V(1,1)}+e^{V(2,1)}} \times \frac{e^{V(1)}}{e^{V(1)}+e^{V(2)}}
\end{aligned}
$$




$$
\pi(\text { Limb 2, Media Threat })=\frac{e^{V(1)}}{e^{V(1)}+e^{V(2)}}
$$

To interpret the regression results, we following Cameron and Trivedi ([9], [13]) in order to obtain Marginal effects (ME), which is the first derivative of the probability functions over an independent variable.

Theoretically,

$$
M E_{n}=\text { Marginal effects }_{n}=\frac{\partial p_{n, j}}{\partial X_{i}(X, \gamma, \lambda)}
$$

where, $n$ represents the $n^{\text {th }}$ observation, $i$ represents the $i^{\text {th }}$ variable of interest and $j$ represents the $j^{\text {th }}$ elemental alternative in relation to the $n^{\text {th }}$ observation.

Consistent with Cameron and Trivedi ([9] [13]), we use finite difference methods by considering an increase of one standard deviation from the sample mean of the variable of interest, excluding indicator variables.

Let $x=(z, d)$, where $z$ is defined as all independent variables other than $d$. Thus, the marginal effects for variable $d$ is, as follows:

$$
M E_{d}=E\left(y \mid z=z^{*}, d=D+\sigma\right)-E\left(y \mid z=z^{*}, d=D\right)
$$

For the indicator variables, we use the following method to get the ME.

$$
M E_{d}=E\left(y \mid z^{*}=z, d=1\right)-E\left(y \mid z=z^{*}, d=0\right)
$$

Following Cameron and Trivede ([9] [13]), for each variable of interest, $d$, we calculate average marginal effects (AME), $\overline{M E_{n}}$ to explain the regression results of a nested logit model:

$$
\overline{M E_{d}}=\sum_{i=1}^{N} \frac{M E_{d, i}}{N}
$$

$N$ is the number of observations and $i$ represents each observation. Interpreting the estimated average marginal effects is that 1 unit increase in $x$ is related to $\mathrm{ME} \%$ increase in $y$, while all other variables remain fixed.

Explaining the nest logit model using the AME is straightforward. It should be noted that the standard errors would not be addressed when the AME is used. Cameron and Trivedi ([13]) pointed out this challenge, however no solution was proffered for it. Also, Jones and Hensher ([8]) attempted to introduce the nested logit model into accounting research but failed to proffer solutions to this challenge. The important fact is that they used $p$-values derived directly from the nested logit models in the discussion of the elasticity. This also implies that the elasticity (marginal effects) and the coefficient estimation have similar p-values. From this review, we follow Jones and Hensher ([8]) and Bethel, Liebeskind and Opler ([14]) and use the p-values obtained directly from the nested logit models in the discussions of marginal effects in Section 4.

\section{Empirical Results}

\subsection{Nested Logit Model-Examination of Assumptions}

In this study, we focus on the period between 2005 and 2007 prior to the occur- 
rence of the financial crisis in 2008. We hand-collected the data regarding proxy contests from Lexis Nexis. The multivariate analysis is used to explore the association between the development of a proxy contest and firm attributes in four aspects: anti-takeover measures, ownership structure, agency costs and firm performance. This will be achieved by using the three-level nested logit models. As seen in Figure 2, the first level shows 6207 observations of Nothing firms (nor proxy contest) and there are 126 occurrences of Media Threat. At the middle level, there are 71 observations of "no further action after media Threat" and 55 cases of SEC filings. The bottom level has 26 cases of "no further action after SEC filing" and 29 proxy fights. Also, in line with Hensher, Ross, and Greene ([12]) the choices of Nothing and "No further action after Media Threat" at the top and the middle level are extended to the bottom, representing two elementary alternatives at the bottom level.

The nested logit model relaxes the restriction of IIA for all the alternatives. Specifically, the IIA assumption test is used to answer the question: Are the odds ratios 'No further action after SEC Filing' and proxy fight actually independent of the presence of the alternatives Nothing and 'No further action after Media Threat'? Following the literature, we use the Hausman specification to test the IIA assumption. This method estimates the conditional logit model on full sample ( $\beta_{\mathrm{a}}$ as estimated coefficients and $\Omega_{\mathrm{a}}$ as estimated covariance matrix) and subsample ( $\beta_{\mathrm{b}}$ as estimated coefficients and $\Omega_{\mathrm{b}}$ as estimated covariance matrix) individually. The sub-sample is created by eliminating choice Nothing from the alternative set and by estimating a three choice model. Thus, 6207 observations under Nothing are eliminated. The new sub-sample has 126 observations of Media Threats nested with 71 cases of 'No further action after Media Threats' and 55 cases of SEC Filing. The latter alternative has 26 events of No further action after SEC Filing and 29 proxy fights. If IIA holds, there should not be any significant differences between the two sets of estimates. Additionally, the quadratic form of $\left(\beta_{\mathrm{a}}-\beta_{\mathrm{b}}\right)^{\prime}\left(\Omega_{\mathrm{a}}-\Omega_{\mathrm{b}}\right)^{-1}\left(\beta_{\mathrm{a}}-\beta_{\mathrm{b}}\right)$ has a chi-square distribution. Figure 3 shows the new tree structure after eliminating Nothing from the sample:

Next, we use total assets, free cash flow, market to book ratio, leverage, prior shareholder proposals, poison pills, board independence, institutional ownership, and block-holder ownership in the Hausman test ([11]), rather than all variables in the nested logit model. This strategy is appropriate due to the small sample size of the subgroup. The purpose of the Hausman test is to demonstrate IIA assumption for some variables; hence, using certain variables while excluding the rest will not affect the conclusion.

Table 1 shows the results. Panels (a) and (b) of Table 1 indicates the estimates from the full sample and sub-sample respectively, applying the conditional logit model. Panel (c) in Table 1 reports the results from the Hausman test. The chi-square value is 121.76, suggesting that the hypothesis that IIA holds can be rejected at the $1 \%$ significance level, indicating that nested logit model is suitable. 


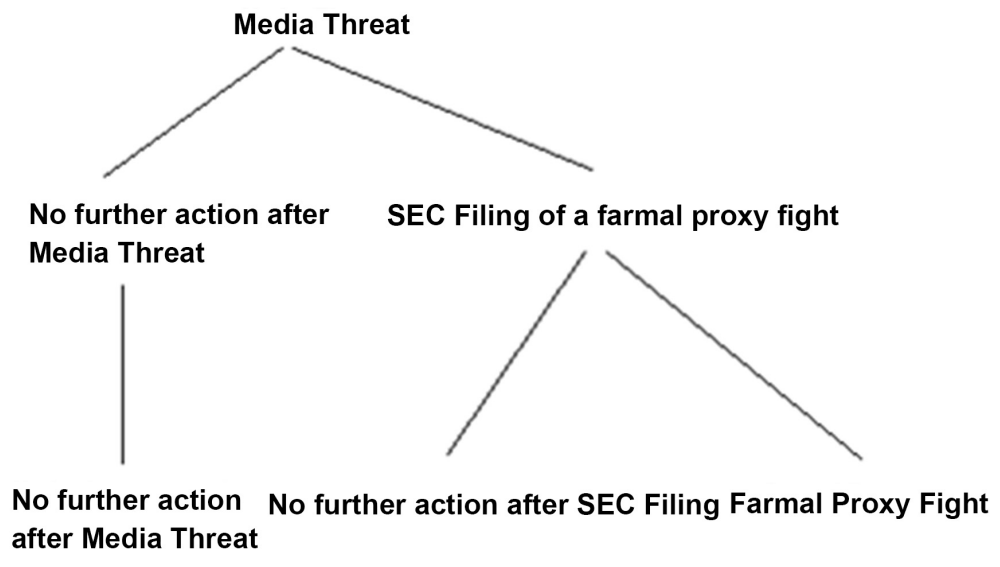

Figure 3. New nested tree structure.

A different approach that can be used to test the IIA assumption is to apply the likelihood ratio test (LRT), which tests the "goodness of fit" between the nested logit model and the conditional nested model. The two models differ only in the dissimilarity parameters, which are set to equal to 1 in the conditional logit model while they are free for estimation in the nested logit model. The LRT uses the following equation to compare the likelihood scores of the two models:

$$
L R=2 \times\left(\ln L_{\text {conditional logit model }}-\ln L_{\text {nested logit model }}\right)
$$

This LRT statistic follows a chi-square distribution. The degree of freedom is equal to the number of additional parameters in the more complete model, which is 2, coming from the dissimilarity parameters for Media Threat and SEC Filing. The dissimilarity parameters for the two degenerate branches are set to one in the nested logit model; this also applies to the conditional logit model. The result of LRT is reported in Table 1 as part of the procedures of a nested logit model. The chi-square is 87.24 , with 2 degrees of freedom. Thus, the IIA assumption is strongly rejected at the $1 \%$ level again, indicating that nested logit model is suitable.

In summary, the IIA assumption does not hold by applying both the Hausman ([11]) test and the likelihood ratio test. Thus, the nested logit model is more appropriate ${ }^{2}$. The detailed utility and probability functions derived from the nested logit model are reported in the Appendix.

\subsection{Graphs Based on Estimated Probabilities}

In this section of the study, we provide the graphs based on the estimated probabilities with the independent variable of interest for Media Threat, SEC Filing, and Proxy Fight, respectively, while holding all the other variables fixed at ${ }^{2} \mathrm{We}$ use Stata 10 to run the nested logit model. Stata 10 produces a nested logit model that is consistent with random utility maximization (RUM) ([1] [10]). We use the default settings for nested logit model under Stata 10. For the numerical root finding method, the default setting is Newton-Raphson algorithm. For the type of variance-covariance matrix, the default is observed information matrix (OIM), the inverse of the negative Hessian matrix ([15]). In addition, all models have no constant variables since all independent variables are non-variant among alternatives, which require keeping one alternative as base in each level and using the interaction between the alternative and the independent variables to create variations in independent variables. 
Table 1. Panel (a): Hausman test on IIA assumption step 1. Panel (b): Hausman test on IIA assumption step 2; Panel (c): Hausman test on IIA assumption results.

(a)

\begin{tabular}{|c|c|c|c|c|c|}
\hline Variable & Alternatives & Coefficient & $\begin{array}{l}\text { Standard } \\
\text { Error }\end{array}$ & $\mathbf{z}$ & $P>|z|$ \\
\hline Market Adjusted Return & SEC Filing & -0.3958 & 0.1611 & -2.46 & 0.014 \\
\hline Poison pills & SEC Filing & -2.1961 & 0.1958 & -11.21 & 0.000 \\
\hline Block-holder ownership & SEC Filing & -20.6261 & 0.8086 & -25.51 & 0.000 \\
\hline Shareholder Proposal Submittal in Prior Year (square root) & SEC Filing & -1.9537 & 0.3268 & -5.98 & 0.000 \\
\hline Industry adjusted Log Total Asset & Voted & 0.0097 & 0.0981 & 0.10 & 0.921 \\
\hline Board Independence & Voted & -4.5999 & 0.6286 & -7.32 & 0.000 \\
\hline Institutional Ownership & Voted & 1.6977 & 0.6260 & 2.71 & 0.007 \\
\hline Industry adjusted Free Cash Flow scaled by total asset & Voted & 0.1305 & 0.0563 & 2.32 & 0.021 \\
\hline Industry adjusted Leverage Ratio (square root) & Voted & 1.0523 & 0.6309 & 1.67 & 0.095 \\
\hline Industry adjusted Log Total Asset & $\begin{array}{c}\text { No further actions after } \\
\text { Media Threat }\end{array}$ & 0.0496 & 0.0722 & 0.69 & 0.492 \\
\hline Board Independence & $\begin{array}{c}\text { No further actions after } \\
\text { Media Threat }\end{array}$ & -4.7647 & 0.4170 & -11.43 & 0.000 \\
\hline Institutional Ownership & $\begin{array}{c}\text { No further actions after } \\
\text { Media Threat }\end{array}$ & -0.6419 & 0.4416 & -1.45 & 0.146 \\
\hline Industry adjusted Free Cash Flow scaled by total asset & $\begin{array}{c}\text { No further actions after } \\
\text { Media Threat }\end{array}$ & -0.1336 & 0.1138 & -1.17 & 0.240 \\
\hline Industry adjusted Log Leverage Ratio & $\begin{array}{c}\text { No further actions after } \\
\text { Media Threat }\end{array}$ & 0.5805 & 0.4494 & 1.29 & 0.196 \\
\hline
\end{tabular}

(b)

\begin{tabular}{|c|c|c|c|c|c|}
\hline Variable & Alternatives & Coefficient & $\begin{array}{l}\text { Standard } \\
\text { Error }\end{array}$ & $\mathbf{z}$ & $P>|z|$ \\
\hline Market Adjusted Return & SEC Filing & 0.5738 & 0.5403 & 1.06 & 0.288 \\
\hline Poison pills & SEC Filing & -0.4999 & 0.3963 & -1.26 & 0.207 \\
\hline Block-holder ownership & SEC Filing & 1.0979 & 1.3033 & 0.84 & 0.400 \\
\hline Shareholder Proposal Submittal in Prior Year (square root) & SEC Filing & -0.1126 & 0.3992 & -0.28 & 0.778 \\
\hline Industry adjusted Log Total Asset & Voted & 0.2616 & 0.1878 & 1.39 & 0.164 \\
\hline Board Independence & Voted & -0.4052 & 1.1974 & -0.34 & 0.735 \\
\hline Institutional Ownership & Voted & -0.1116 & 1.2683 & -0.09 & 0.930 \\
\hline Industry adjusted Free Cash Flow scaled by total asset & Voted & -0.0249 & 0.0937 & -0.27 & 0.791 \\
\hline Industry adjusted Leverage Ratio (square root) & Voted & 0.0052 & 1.0325 & 0.01 & 0.996 \\
\hline Industry adjusted Log Total Asset & $\begin{array}{c}\text { No further actions after } \\
\text { Media Threat }\end{array}$ & 0.1370 & 0.1830 & 0.75 & 0.454 \\
\hline Board Independence & $\begin{array}{l}\text { No further actions after } \\
\text { Media Threat }\end{array}$ & 1.8810 & 1.1284 & 1.67 & 0.096 \\
\hline Institutional Ownership & $\begin{array}{c}\text { No further actions after } \\
\text { Media Threat }\end{array}$ & -0.7339 & 1.2074 & -0.61 & 0.543 \\
\hline Industry adjusted Free Cash Flow scaled by total asset & $\begin{array}{c}\text { No further actions after } \\
\text { Media Threat }\end{array}$ & -0.3579 & 0.1706 & -2.10 & 0.036 \\
\hline Industry adjusted Log Leverage Ratio & $\begin{array}{c}\text { No further actions after } \\
\text { Media Threat }\end{array}$ & -0.4258 & 0.9941 & -0.43 & 0.668 \\
\hline
\end{tabular}


(c)

\begin{tabular}{|c|c|c|c|c|}
\hline \multirow[b]{2}{*}{ Variables } & \multicolumn{4}{|c|}{ Coefficients } \\
\hline & Alternatives & fullest (a) & Subset (b) & Difference (a-b) \\
\hline Market Adjusted Return & SEC Filing & -0.3958 & 0.5738 & -0.9697 \\
\hline Poison pills & SEC Filing & -2.1961 & -0.4999 & -1.6962 \\
\hline Block-holder ownership & SEC Filing & -20.6261 & 1.0979 & -21.7239 \\
\hline Shareholder Proposal Submittal in Prior Year (square root) & SEC Filing & -1.9537 & -0.1126 & -1.8412 \\
\hline Industry adjusted Log Total Asset & Voted & 0.0097 & 0.2616 & -0.2519 \\
\hline Board Independence & Voted & -4.5999 & -0.4052 & -4.1947 \\
\hline Institutional Ownership & Voted & 1.6977 & -0.1116 & 1.8092 \\
\hline Industry adjusted Free Cash Flow scaled by total asset & Voted & 0.1305 & -0.0249 & 0.1553 \\
\hline Industry adjusted Leverage Ratio (square root) & Voted & 1.0523 & 0.0052 & 1.0471 \\
\hline Industry adjusted Log Total Asset & $\begin{array}{c}\text { No further actions after } \\
\text { Media Threat }\end{array}$ & 0.0496 & 0.1370 & -0.0875 \\
\hline Board Independence & $\begin{array}{c}\text { No further actions after } \\
\text { Media Threat }\end{array}$ & -4.7647 & 1.8810 & -6.6457 \\
\hline Institutional Ownership & $\begin{array}{c}\text { No further actions after } \\
\text { Media Threat }\end{array}$ & -0.6419 & -0.7339 & 0.0920 \\
\hline Industry adjusted Free Cash Flow scaled by total asset & $\begin{array}{c}\text { No further actions after } \\
\text { Media Threat }\end{array}$ & -0.1336 & -0.3579 & 0.2244 \\
\hline Industry adjusted Log Leverage Ratio & $\begin{array}{c}\text { No further actions after } \\
\text { Media Threat }\end{array}$ & 0.5805 & -0.4258 & 1.0064 \\
\hline
\end{tabular}

This is the last step in testing IIA assumption. This last step is to calculate $\left(\beta_{\mathrm{a}}-\beta_{\mathrm{b}}\right)^{\prime}\left(\Omega_{\mathrm{a}}-\Omega_{\mathrm{b}}\right)^{-1}\left(\beta_{\mathrm{a}}-\beta_{\mathrm{b}}\right) \cdot \beta_{\mathrm{a}}$ and $\beta_{\mathrm{b}}$ are from step one and step two respectively and $\Omega_{\mathrm{a}}$ and $\Omega_{\mathrm{b}}$ are covariance matrix. $\left(\beta_{\mathrm{a}}-\beta_{\mathrm{b}}\right)^{\prime}\left(\Omega_{\mathrm{a}}-\Omega_{\mathrm{b}}\right)^{-1}\left(\beta_{\mathrm{a}}-\beta_{\mathrm{b}}\right)$ has a chi-square distribution when IIA holds, with two degree of freedom in this test. Chi-square $=\left(\beta_{\mathrm{a}}-\beta_{\mathrm{b}}\right)^{\prime}\left(\Omega_{\mathrm{a}}-\Omega_{\mathrm{b}}\right)^{-1}\left(\beta_{\mathrm{a}}-\beta_{\mathrm{b}}\right)=1$ 21.76. Prob $>\mathrm{chi}^{2}=0.0000$. Notes: 1$) \mathrm{a}=$ consistent under $\mathrm{H}_{0}$ and Ha obtained from conditional logit model 1 . 2) $\mathrm{b}=$ inconsistent under Ha, efficient under $\mathrm{H}_{0}$ obtained from conditional logit model 2. 3) Test: $\mathrm{H}_{0}$ : difference in coefficients is not systematic. 4) $\Omega_{\mathrm{a}}-\Omega_{\mathrm{b}}$ is not positive definite.

sample mean, except for indicator variables whose values equal to one for all observations. Figure 4 plots the marginal probabilities of Media Threat for holding period return. Figure 5 and Figure 6 plot the marginal probabilities of SEC Filing for board independence level and the proxy fight for insider ownership, respectively. The estimated probabilities seem a little low. This might be because proxy contests are rare corporate events.

Figure 4 shows that when holding period return increases, the estimated probability of a media threat tends to drop.

Figure 5 shows that when board independence level increases, the estimated probability of a SEC filing tends to drop. However, when board independence level is more than $80 \%$, the possibility of a SEC filing might increase.

Figure 6 shows that when board insiders' ownership increases, the estimated probability of a formal proxy fight tends to fall.

\section{Conclusions}

In this study, we have illustrated how the nested logit model can be effectively used to evaluate a case of a proxy contest. The nested logit model is suitable for situations that are associated with the development of a case which can be divided 


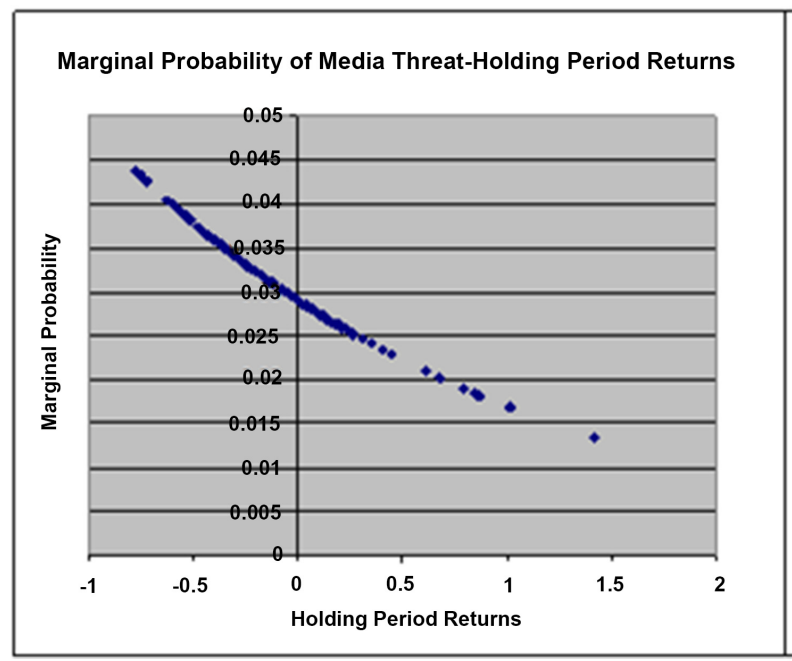

Figure 4. Marginal probability of media threat and stock returns.

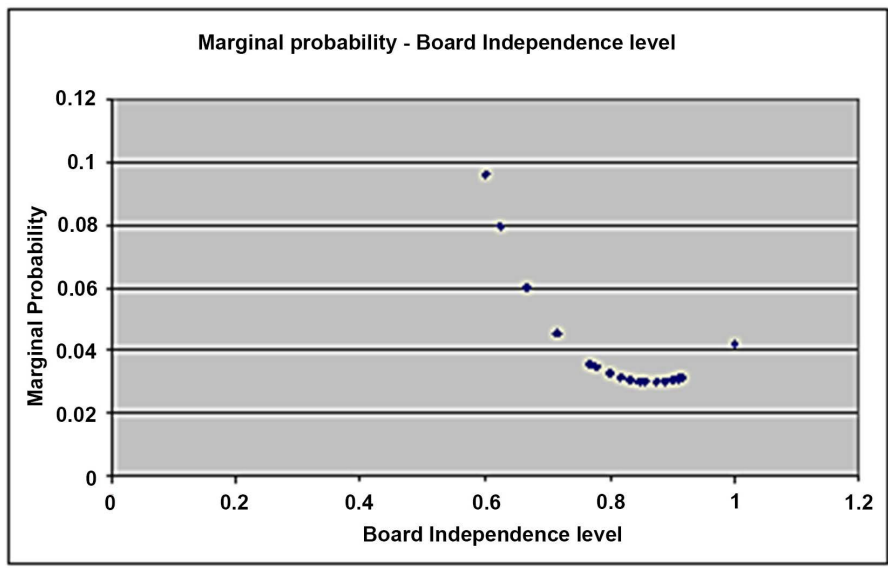

Figure 5. Marginal probability of SEC Filing \& board independence.

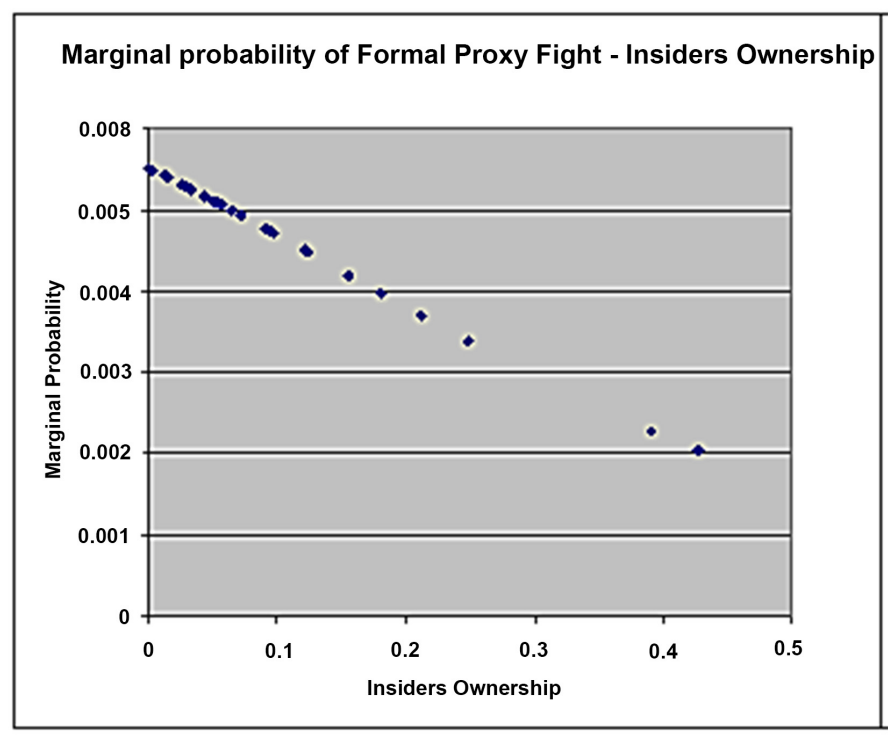

Figure 6. Marginal probability of proxy fight and insider ownership. 
into different stages with each stage having multiple outcomes from which a choice can be made. In the context of the proxy contest, the development is in the following order:

Media Threat $\rightarrow$ SEC Filing $\rightarrow$ Proxy Fight

Under each stage, the activist can abandon the fight or proceed to the next level. This makes the nested logit model an appropriate study tool.

\section{Conflicts of Interest}

The authors declare no conflicts of interest regarding the publication of this paper.

\section{References}

[1] Heiss, F. (2002) Structural Choice Analysis with Nested Logit Models. The Stata Journal, 2, 227-252. https://doi.org/10.1177/1536867X0200200301

[2] Greene, W. (2002) Econometric Analysis. Prentice Hall, Upper Saddle River.

[3] Bratton, W. (2007) Hedge Funds and Governance Targets. Georgetown Law Journal, 95, 1307-1433.

[4] Clifford, C. (2008) Value Creation or Destruction? Hedge Funds as Shareholder Activists. Journal of Corporate Finance, 14, 323-336. https://doi.org/10.1016/j.jcorpfin.2008.04.007

[5] Gillan, S. and Starks, L. (2000) Corporate Governance Proposals and Shareholder Activism: The Role of Institutional Investors. Journal of Financial Economics, 57, 275-305. https://doi.org/10.1016/S0304-405X(00)00058-1

[6] Gillan, S. and Starks, L. (2007) The Evolution of Shareholder Activism in the United States. Journal of Applied Corporate Finance, 19, 55-73. https://doi.org/10.1111/j.1745-6622.2007.00125.x

[7] Renneboog, L. and Szilagyi, P. (2011) The Role of Shareholder Proposals in Corporate Governance. Journal of Corporate Finance, 17, 167-188. https://doi.org/10.1016/j.jcorpfin.2010.10.002

[8] Jones, S. and Hensher, D. (2007) Modeling Corporate Failure: A Multinomial Nested Logit Analysis for Unordered Outcomes. The British Accounting Review, 39, 89-107. https://doi.org/10.1016/j.bar.2006.12.003

[9] Cameron, A.C. and Trivedi, P.K. (2005) Microeconometrics with Methods and Application. Cambridge University Press, Cambridge. https://doi.org/10.1017/CBO9780511811241

[10] Stata10 Reference I-P Reference Manual, 2007. Stata Press, College Station.

[11] Hausman, J.A. (1978) Specification Tests in Econometrics. Econometrica, 46, 1251-1271. https://doi.org/10.2307/1913827

[12] Hensher, D., Rose, J. and Greene, W. (2005) Applied Choice Analysis: A Primer. Cambridge University Press, Cambridge. https://doi.org/10.1017/CBO9780511610356

[13] Cameron, A.C. and Trivedi, P.K. (2009) Microeconometrics Using Stata. Stata Press, College Station.

[14] Bethel, J., Liebeskind, J. and Opler, T. (1998) Block Share Purchases and Corporate Performance. Journal of Finance, 53, 605-634. https://doi.org/10.1111/0022-1082.244195

[15] Gould, W., Pitblado, J. and Sribney, W. (2006) Maxium Likelihood Estimation with Stata. 3rd Edition, Stata Press, College Station. 


\section{Appendix-The Functions of the Nested Logit Model}

The coefficients and average marginal effects estimated from the nested logit model are reported in Panel (a) of Table A1. Based on the coefficients, we obtain the estimated utility functions and derive the estimated probability functions. They are, as follows:

Utility Functions:

In general, $U_{n j}=V_{n j}+\varepsilon_{n j}$, where $V_{n j}$ is observed by the researcher and $\varepsilon_{n j}$ is a random variable whose value is not observable. Additionally, $n$ represents the $n^{\text {th }}$ observations and $j$ represents the $f^{\text {th }}$ alternatives.

$$
\begin{aligned}
& V_{\text {Media Threat }} \\
& =18.44 \times(-0.16 \times \mathrm{TA}-0.55 \times \mathrm{HPR}+0.08 \times \mathrm{FCF}+0.31 \times \text { Leverage } \\
& -1.05 \times \mathrm{MTB}+0.60 \times \text { Proposal }-1 / 71.20 \times \ln (\exp (0.18 \times \text { Stagger } \\
& +2.62 \times \text { Poison }+0.54 \times \text { Merger }-28.96 \times \text { Boardindep }-0.47 \times \text { Bylaw } \\
& +2.26 \times \text { Charter })+\exp (-0.89 \times \text { Stagger }-2.19 \times \text { Poison }-0.93 \times \text { Merger } \\
& +36.72 \times \text { Boardindep }+1.34 \times \text { Bylaw }-3.90 \times \text { Charter }) \\
& +\ln \left(\mathrm{e}^{\wedge}(0.54 \times \text { institutional }-19.91 \times \text { Block-holder }+30.36 \times \text { Insiders }\right. \\
& -0.0011 \times \text { fund_no }+11.899 \times \text { filing_13d })+\mathrm{e}^{\wedge}(0.26 \times \text { institutional } \\
& +22.40 \times \text { Block-holder }-34.86 \times \text { Insiders }+0.004 \times \text { fund_no } \\
& -11.30 \times \text { filing_13d)) } \\
& V_{\text {No further actions after Media Threat|Media Threat }} \\
& =-71.20 \times(0.18 \times \text { Stagger }+2.62 \times \text { Poison }+0.54 \times \text { Merger } \\
& -28.96 \times \text { Boardindep }-0.47 \times \text { Bylaw }+2.26 \times \text { Charter }) \\
& V_{\text {SEC Filing|Media Threat }} \\
& =-71.20 \times(-0.89 \times \text { Stagger }-2.19 \times \text { Poison }-0.93 \times \text { Merger } \\
& +36.72 \times \text { Boardindep }+1.34 \times \text { Bylaw }-3.90 \times \text { Charter } \\
& +\ln \left(\mathrm{e}^{\wedge}(0.54 \times \text { institutional }-19.91 \times \text { Block-holder }\right. \\
& +30.06 \times \text { Insiders }-0.0011 \times \text { fund_no }+11.899 \times \text { filing_13d) } \\
& +\mathrm{e}^{\wedge}(0.26 \times \text { institutional }+22.40 \times \text { Block-holder } \\
& -34.86 \times \text { Insiders }+0.004 \times \text { fund_no }-11.30 \times \text { filing_13d)) } \\
& V_{\text {No further actions after SEC Filing|SEC Filing }} \\
& =0.54 \times \text { institutional }-19.91 \times \text { Block-holder }+30.36 \times \text { Insiders } \\
& -0.0011 \times \text { fund_no }+11.899 \times \text { filing_13d } \\
& V_{\text {Proxy fight|SEC Filing }} \\
& =0.26 \times \text { institutional }+22.40 \times \text { Block-holder }-34.86 \times \text { Insiders } \\
& +0.004 \times \text { fund_no }-11.30 \times \text { filing_13d } \\
& \text { Probability Functions: }
\end{aligned}
$$


Table A1. Panel (a): Nested logistic regression results; Panel (b): Nested logistic regression results—dissimilarity parameters.

(a)

\begin{tabular}{|c|c|c|c|c|c|}
\hline Variable & Alternative & Coefficient & Marginal Effects & $\mathrm{Z}$ value & $P>|z|$ \\
\hline Industry adjusted Log Total Asset & Media Threat & $-0.1643^{\star}$ & -0.0032 & -1.92 & 0.055 \\
\hline Market Adjusted Return & Media Threat & $-0.5509^{*}$ & -0.0106 & -1.94 & 0.053 \\
\hline $\begin{array}{l}\text { Industry adjusted Free Cash Flow scaled by total } \\
\text { asset }\end{array}$ & Media Threat & $0.0785^{\star *}$ & 0.0015 & 2.12 & 0.034 \\
\hline Industry adjusted Leverage Ratio (square root) & Media Threat & 0.3080 & 0.0059 & 0.78 & 0.435 \\
\hline Industry adjusted Log Market to Book Ratio & Media Threat & $-1.0484^{* * *}$ & -0.0202 & -3.83 & 0.000 \\
\hline $\begin{array}{l}\text { Shareholder Proposal Submittal in Prior Year } \\
\text { (square root) }\end{array}$ & Media Threat & $0.5966^{* * *}$ & 0.0115 & 2.75 & 0.006 \\
\hline Staggered Board & No further actions after Media Threat & 0.1817 & 0.0012 & 0.18 & 0.856 \\
\hline Poison pills & No further actions after Media Threat & $2.6244^{\star *}$ & 0.0198 & 2.34 & 0.019 \\
\hline Requirement to Approve a Merger & No further actions after Media Threat & 0.5419 & 0.0040 & 0.34 & 0.738 \\
\hline Requirement to Amend Bylaws & No further actions after Media Threat & -0.4679 & -0.0029 & -0.39 & 0.696 \\
\hline Requirement to Amend Company Charter & No further actions after Media Threat & 2.2630 & 0.0280 & 1.09 & 0.276 \\
\hline Board Independence & No further actions after Media Threat & $-28.9569^{* * *}$ & -0.1254 & -3.25 & 0.001 \\
\hline Staggered Board & SEC Filing & -0.8908 & -0.0037 & -0.68 & 0.498 \\
\hline Poison pills & SEC Filing & -2.1897 & -0.0100 & -1.51 & 0.13 \\
\hline Requirement to Approve a Merger & SEC Filing & -0.9289 & -0.0032 & -0.41 & 0.681 \\
\hline Requirement to Amend Bylaws & SEC Filing & 1.3447 & 0.0065 & 0.87 & 0.382 \\
\hline Requirement to Amend Company Charter & SEC Filing & -3.8977 & -0.0083 & -1.06 & 0.29 \\
\hline Board Independence & SEC Filing & $36.7119^{* * *}$ & 0.1468 & 3.46 & 0.001 \\
\hline Institutional Ownership & No further actions after SEC Filing & 0.5389 & 0.0005 & 0.06 & 0.955 \\
\hline Number of funds & No further actions after SEC Filing & -0.0011 & 0.0000 & -0.09 & 0.93 \\
\hline Insider ownership & No further actions after SEC Filing & 30.3590 & 0.0306 & 1.08 & 0.282 \\
\hline Block-holder ownership & No further actions after SEC Filing & -19.9147 & -0.0201 & -1.41 & 0.158 \\
\hline Filing of $13 \mathrm{~d}-$ Presence of active block-holders & No further actions after SEC Filing & 11.8989 & 0.0766 & 1.14 & 0.254 \\
\hline Institutional Ownership & Proxy Fight & 0.2603 & 0.0002 & 0.03 & 0.979 \\
\hline Number of funds & Proxy Fight & 0.0041 & 0.0000 & 0.31 & 0.76 \\
\hline Insider ownership & Proxy Fight & $-34.8581^{\star}$ & -0.0329 & -1.72 & 0.085 \\
\hline Block-holder ownership & Proxy Fight & 22.4023 & 0.0212 & 1.21 & 0.225 \\
\hline Filing of $13 \mathrm{~d}-$ Presence of active block-holders & Proxy Fight & -11.3002 & -0.0292 & -1.32 & 0.186 \\
\hline
\end{tabular}

The Table shows the direct regression outcome of the nested logit models under Stata 10 that are consistent with Random Utility Maximization (RUM). The alternatives are as defined in Figure 1. Nothing and No further actions after Media Threat are with degenerate nodes and are therefore extended to the bottom level as elementary alternatives. Out of the total of 6333 firms in TCL in the sample period, 6207 of them are not targets of activists for proxy fights. They belong to the Nothing group. 126 firms (Media Threat) are threatened by activists via media, among which 55 firms (SEC Filing) are threatened further when activists file form DEFC14A with the SEC. Only 29 firms end proxy fights via shareholder voting (proxy fight). Average marginal effects are reported. Stock returns for each firm are collected from CRSP and are calculated on a fiscal year basis. Accounting information is taken from COMPUSTAT. Free cash flows are calculated by subtracting capital expenditures (Schedule V) of property, plant and equipment from operating income before depreciation and scaled by total assets. Leverage equals the sum of long term debt and short term debt and then divided by total assets. Market to book ratio equals the sum of total assets and the product of stock price at the end of the fiscal year and outstanding common shares, minus total equity and then divided by total asset. Firm size equals total assets. Firm size and market to book ratio is transformed by log and leverage by square root to reduce kurtosis and skewness. Additionally, to control for the industry effect, all of the above accounting variables are adjusted by industry means. We collected the status of classified boards and poison pills, percentage of outstanding shares required to amend bylaws, percentage of outstanding shares required to amend company charter and percentage of outstanding shares required to approve a merger or sale from TCL. Where the percentage of the above three variables is greater than $66.67 \%$, the thresholds for super majority, it is recorded as 1 . Otherwise, it is recorded as 0. Additionally, board size and number of outside directors from TCL is recorded to ascertain the level of board independence. Quarterly ownership by institutional investors from the Thompson CDA/Spectrum $13 \mathrm{~F}$ institutional ownership data is collected for the sample. We also divided the sample into five groups by manager type code as defined in Thompson. We then calculated the aggregate ownership and counted the number of funds by all institutional investors and by each manager type. Ownership by insiders and block-holders as listed in TCL, is also collected. Shareholder proposal data is collected from Investor Responsibility Research Center (IRRC). 
(b)

\begin{tabular}{ccc}
\hline Level and Alternatives & Dissimilarity Parameters & Standard Error \\
\hline $\begin{array}{c}\text { Top Level } \\
\text { Nothing (limb 1) }\end{array}$ & 1 & 18.4435 \\
Media Threat & & 8.9097 \\
Middle Level & 1 & 1 \\
Nothing (branch 1) & -71.1981 & 23.6095 \\
No further actions after Media Threat (branch 2) & \\
\hline
\end{tabular}

The Table shows the dissimilarity parameters for the top level and middle level. The table also reports the likelihood ratio test result for IIA assumption. The alternatives are defined in Figure 1. Nothing and No further actions after Media Threat are with degenerate nodes and are extended to the bottom level as elementary alternatives. Their corresponding dissimilarity parameters are defined as $1([10])$. Likelihood ratio test $\left(\right.$ LR) for IIA $($ tau $=1)$ : chi ${ }^{2}(2)=87.24$ Prob $>\mathrm{chi}^{2}=0.0000$.

$$
\begin{aligned}
& \pi_{\text {Nothing }} \\
& =1 /(1+\exp (18.44 \times(-0.16 \times \mathrm{TA}-0.55 \times \mathrm{HPR}+0.08 \times \mathrm{FCF}+0.31 \times \text { Leverage } \\
& -1.05 \times \mathrm{MTB}+0.60 \times \text { Proposal }-1 / 71.20 \times \ln (\exp (0.18 \times \text { Stagger } \\
& +2.62 \times \text { Poison }+0.54 \times \text { Merger }-28.96 \times \text { Boardindep }-0.47 \times \text { Bylaw } \\
& +2.26 \times \text { Charter })+\exp (-0.89 \times \text { Stagger }-2.19 \times \text { Poison }-0.93 \times \text { Merger } \\
& +36.72 \times \text { Boardindep }+1.34 \times \text { Bylaw }-3.90 \times \text { Charter) } \\
& +\ln \left(\mathrm{e}^{\wedge}(0.54 \times \text { institutional }-19.91 \times \text { Block-holder }+30.36 \times \text { Insiders }\right. \\
& -0.0011 \times \text { fund_no }+11.899 \times \text { filing_13d })+\mathrm{e}^{\wedge}(0.26 \times \text { institutional } \\
& +22.40 \times \text { Block-holder }-34.86 \times \text { Insiders }+0.004 \times \text { fund_no } \\
& -11.30 \times \text { filing_13d)) )) } \\
& \pi_{\text {Media Threat }} \\
& =\exp (18.44 \times(-0.16 \times \mathrm{TA}-0.55 \times \mathrm{HPR}+0.08 \times \mathrm{FCF}+0.31 \times \text { Leverage } \\
& -1.05 \times \mathrm{MTB}+0.60 \times \text { Proposal }-1 / 71.20 \times \ln (\exp (0.18 \times \text { Stagger } \\
& +2.62 \times \text { Poison }+0.54 \times \text { Merger }-28.96 \times \text { Boardindep }-0.47 \times \text { Bylaw } \\
& +2.26 \times \text { Charter })+\exp (-0.89 \times \text { Stagger }-2.19 \times \text { Poison }-0.93 \times \text { Merger } \\
& +36.72 \times \text { Boardindep }+1.34 \times \text { Bylaw }-3.90 \times \text { Charter }) \\
& +\ln \left(\mathrm{e}^{\wedge}(0.54 \times \text { institutional }-19.91 \times \text { Block-holder }+30.36 \times \text { Insiders }\right. \\
& -0.0011 \times \text { fund_no }+11.899 \times \text { filing_ } 13 \mathrm{~d})+\mathrm{e}^{\wedge}(0.26 \times \text { institutional } \\
& +22.40 \times \text { Block-holder }-34.86 \times \text { Insiders }+0.004 \times \text { fund no } \\
& -11.30 \times \text { filing_13d }))) /(1+\exp (18.44 \times(-0.16 \times \text { TA }-0.55 \times \text { HPR } \\
& +0.08 \times \mathrm{FCF}+0.31 \times \text { Leverage }-1.05 \times \mathrm{MTB}+0.60 \times \text { Proposal } \\
& -1 / 71.20 \times \ln (\exp (0.18 \times \text { Stagger }+2.62 \times \text { Poison }+0.54 \times \text { Merger } \\
& -28.96 \times \text { Boardindep }-0.47 \times \text { Bylaw }+2.26 \times \text { Charter) } \\
& +\exp (-0.89 \times \text { Stagger }-2.19 \times \text { Poison }-0.93 \times \text { Merger } \\
& +36.72 \times \text { Boardindep }+1.34 \times \text { Bylaw }-3.90 \times \text { Charter })
\end{aligned}
$$


$+\ln \left(\mathrm{e}^{\wedge}(0.54 \times\right.$ institutional $-19.91 \times$ Block-holder $+30.36 \times$ Insiders

$-0.0011 \times$ fund_no $+11.899 \times$ filing_13d $)+\mathrm{e}^{\wedge}(0.26 \times$ institutional

$+22.40 \times$ Block-holder $-34.86 \times$ Insiders $+0.004 \times$ fund_no

$-11.30 \times$ filing_13d)) ))

$\pi_{\text {Closed after Media Threat|Media Threa }}$

$=\exp (-71.20 \times(0.18 \times$ Stagger $+2.62 \times$ Poison $+0.54 \times$ Merger

$-28.96 \times$ Boardindep $-0.47 \times$ Bylaw $+2.26 \times$ Charter $)) /$

$\exp (-71.20 \times(0.18 \times$ Stagger $+2.62 \times$ Poison $+0.54 \times$ Merger

$-28.96 \times$ Boardindep $-0.47 \times$ Bylaw $+2.26 \times$ Charter $)$ )

$+\exp (-71.20 \times(-0.89 \times$ Stagger $-2.19 \times$ Poison $-0.93 \times$ Merger

$+36.72 \times$ Boardindep $+1.34 \times$ Bylaw $-3.90 \times$ Charter $)$

$+\ln \left(\mathrm{e}^{\wedge}(0.54 \times\right.$ institutional $-19.91 \times$ Block-holder $+30.36 \times$ Insiders

$-0.0011 \times$ fund_no $+11.899 \times$ filing_13d $)+\mathrm{e}^{\wedge}(0.26 \times$ institutional

$+22.40 \times$ Block-holder $-34.86 \times$ Insiders $+0.004 \times$ fund_no

$-11.30 \times$ filing_13d)) )

$\pi_{\text {SEC Filing|Media Threat }}$

$=\exp (-71.20 \times(-0.89 \times$ Stagger $-2.19 \times$ Poison $-0.93 \times$ Merger

$+36.72 \times$ Boardindep $+1.34 \times$ Bylaw $-3.90 \times$ Charter $)$

$+\ln \left(\mathrm{e}^{\wedge}(0.54 \times\right.$ institutional $-19.91 \times$ Block-holder $+30.36 \times$ Insiders

$-0.0011 \times$ fund_no $+11.899 \times$ filing_13d $)+\mathrm{e}^{\wedge}(0.26 \times$ institutional

$+22.40 \times$ Block-holder $-34.86 \times$ Insiders $+0.004 \times$ fund_no

$-11.30 \times$ filing_13d $))) / \exp (-71.20 \times(0.18 \times$ Stagger $+2.62 \times$ Poison

$+0.54 \times$ Merger $-28.96 \times$ Boardindep $-0.47 \times$ Bylaw $+2.26 \times$ Charter $)$ )

$+\exp (-71.20 \times(-0.89 \times$ Stagger $-2.19 \times$ Poison $-0.93 \times$ Merger

$+36.72 \times$ Boardindep $+1.34 \times$ Bylaw $-3.90 \times$ Charter $)$

$+\ln \left(\mathrm{e}^{\wedge}(0.54 \times\right.$ institutional $-19.91 \times$ Block-holder $+30.36 \times$ Insiders

$-0.0011 \times$ fund_no $+11.899 \times$ filing_13d $)+\mathrm{e}^{\wedge}(0.26 \times$ institutional

$+22.40 \times$ Block-holder $-34.86 \times$ Insiders $+0.004 \times$ fund_no

$-11.30 \times$ filing_13d))

$\pi_{\text {SEC Filing }}=\pi_{\text {Media Threat }} \times \pi_{\text {SEC Filing|Media Threat }}$

$=\exp (18.44 \times(-0.16 \times \mathrm{TA}-0.55 \times \mathrm{HPR}+0.08 \times \mathrm{FCF}+0.31 \times$ Leverage

$-1.05 \times \mathrm{MTB}+0.60 \times$ Proposal $-1 / 71.20 \times \ln (\exp (0.18 \times$ Stagger

$+2.62 \times$ Poison $+0.54 \times$ Merger $-28.96 \times$ Boardindep $-0.47 \times$ Bylaw

$+2.26 \times$ Charter $)+\exp (-0.89 \times$ Stagger $-2.19 \times$ Poison $-0.93 \times$ Merger

$+36.72 \times$ Boardindep $+1.34 \times$ Bylaw $-3.90 \times$ Charter $)$

$+\ln \left(\mathrm{e}^{\wedge}(0.54 \times\right.$ institutional $-19.91 \times$ Block-holder $+30.36 \times$ Insiders

$-0.0011 \times$ fund_no $+11.899 \times$ filing_ $13 \mathrm{~d})+\mathrm{e}^{\wedge}(0.26 \times$ institutional

$+22.40 \times$ Block-holder $-34.86 \times$ Insiders $+0.004 \times$ fund no

$-11.30 \times$ filing_13d $))) /(1+\exp (18.44 \times(-0.16 \times$ TA $-0.55 \times$ HPR 


$$
\begin{aligned}
& +0.08 \times \mathrm{FCF}+0.31 \times \text { Leverage }-1.05 \times \mathrm{MTB}+0.60 \times \text { Proposal } \\
& -1 / 71.20 \times \ln (\exp (0.18 \times \text { Stagger }+2.62 \times \text { Poison }+0.54 \times \text { Merger } \\
& -28.96 \times \text { Boardindep }-0.47 \times \text { Bylaw }+2.26 \times \text { Charter) } \\
& +\exp (-0.89 \times \text { Stagger }-2.19 \times \text { Poison }-0.93 \times \text { Merger } \\
& +36.72 \times \text { Boardindep }+1.34 \times \text { Bylaw }-3.90 \times \text { Charter) } \\
& +\ln \left(\mathrm{e}^{\wedge}(0.54 \times \text { institutional }-19.91 \times \text { Block-holder }+30.36 \times \text { Insiders }\right. \\
& -0.0011 \times \text { fund_no }+11.899 \times \text { filing_ } 13 \mathrm{~d})+\mathrm{e}^{\wedge}(0.26 \times \text { institutional } \\
& +22.40 \times \text { Block-holder }-34.86 \times \text { Insiders }+0.004 \times \text { fund_no } \\
& -11.30 \times \text { filing_13d })))) \times \exp (-71.20 \times(-0.89 \times \text { Stagger }-2.19 \times \text { Poison } \\
& -0.93 \times \text { Merger }+36.72 \times \text { Boardindep }+1.34 \times \text { Bylaw }-3.90 \times \text { Charter) } \\
& +\ln \left(\mathrm{e}^{\wedge}(0.54 \times \text { institutional }-19.91 \times \text { Block-holder }+30.36 \times \text { Insiders }\right. \\
& -0.0011 \times \text { fund_no }+11.899 \times \text { filing_13d })+\mathrm{e}^{\wedge}(0.26 \times \text { institutional } \\
& +22.40 \times \text { Block-holder }-34.86 \times \text { Insiders }+0.004 \times \text { fund_no } \\
& -11.30 \times \text { filing_13d }))) / \exp (-71.20 \times(0.18 \times \text { Stagger }+2.62 \times \text { Poison } \\
& +0.54 \times \text { Merger }-28.96 \times \text { Boardindep }-0.47 \times \text { Bylaw }+2.26 \times \text { Charter }) \text { ) } \\
& +\exp (-71.20 \times(-0.89 \times \text { Stagger }-2.19 \times \text { Poison }-0.93 \times \text { Merger } \\
& +36.72 \times \text { Boardindep }+1.34 \times \text { Bylaw }-3.90 \times \text { Charter }) \\
& +\ln \left(\mathrm{e}^{\wedge}(0.54 \times \text { institutional }-19.91 \times \text { Block-holder }+30.36 \times \text { Insiders }\right. \\
& -0.0011 \times \text { fund_no }+11.899 \times \text { filing_13d })+\mathrm{e}^{\wedge}(0.26 \times \text { institutional } \\
& +22.40 \times \text { Block-holder }-34.86 \times \text { Insiders }+0.004 \times \text { fund_no } \\
& -11.30 \times \text { filing_13d)) } \\
& \pi_{\text {proxy fight|SEC Filing }} \\
& =\mathrm{e}^{\wedge}(0.26 \times \text { institutional }+22.40 \times \text { Block-holder }-34.86 \times \text { Insiders } \\
& +0.004 \times \text { fund_no }-11.30 \times \text { filing_13d }) /\left(\mathrm{e}^{\wedge}(0.54 \times \text { institutional }\right. \\
& -19.91 \times \text { Block-holder }+30.36 \times \text { Insiders }-0.0011 \times \text { fund_no } \\
& +11.899 \times \text { filing_13d })+\mathrm{e}^{\wedge}(0.26 \times \text { institutional }+22.40 \times \text { Block-holder } \\
& -34.86 \times \text { Insiders }+0.004 \times \text { fund_no }-11.30 \times \text { filing_13d)) } \\
& \pi_{\text {proxy fight }}=\pi_{\text {Media Threat }} \times \pi_{\text {SEC Filing|Media Threat }} \times \pi_{\text {proxy fight|SEC Filing }} \\
& =\exp (18.44 \times(-0.16 \times \mathrm{TA}-0.55 \times \mathrm{HPR}+0.08 \times \mathrm{FCF}+0.31 \times \text { Leverage } \\
& -1.05 \times \mathrm{MTB}+0.60 \times \text { Proposal }-1 / 71.20 \times \ln (\exp (0.18 \times \text { Stagger } \\
& +2.62 \times \text { Poison }+0.54 \times \text { Merger }-28.96 \times \text { Boardindep }-0.47 \times \text { Bylaw } \\
& +2.26 \times \text { Charter })+\exp (-0.89 \times \text { Stagger }-2.19 \times \text { Poison }-0.93 \times \text { Merger } \\
& +36.72 \times \text { Boardindep }+1.34 \times \text { Bylaw }-3.90 \times \text { Charter }) \\
& +\ln \left(\mathrm{e}^{\wedge}(0.54 \times \text { institutional }-19.91 \times \text { Block-holder }+30.36 \times \text { Insiders }\right. \\
& -0.0011 \times \text { fund_no }+11.899 \times \text { filing_13d })+\mathrm{e}^{\wedge}(0.26 \times \text { institutional } \\
& +22.40 \times \text { Block-holder }-34.86 \times \text { Insiders }+0.004 \times \text { fund_no } \\
& -11.30 \times \text { filing_13d }))) /(1+\exp (18.44 \times(-0.16 \times \text { TA }-0.55 \times \text { HPR }
\end{aligned}
$$


$+0.08 \times \mathrm{FCF}+0.31 \times$ Leverage $-1.05 \times \mathrm{MTB}+0.60 \times$ Proposal

$-1 / 71.20 \times \ln (\exp (0.18 \times$ Stagger $+2.62 \times$ Poison $+0.54 \times$ Merger

$-28.96 \times$ Boardindep $-0.47 \times$ Bylaw $+2.26 \times$ Charter)

$+\exp (-0.89 \times$ Stagger $-2.19 \times$ Poison $-0.93 \times$ Merger

$+36.72 \times$ Boardindep $+1.34 \times$ Bylaw $-3.90 \times$ Charter $)$

$+\ln \left(\mathrm{e}^{\wedge}(0.54 \times\right.$ institutional $-19.91 \times$ Block-holder $+30.36 \times$ Insiders

$-0.0011 \times$ fund_no $+11.899 \times$ filing_13d $)+\mathrm{e}^{\wedge}(0.26 \times$ institutional

$+22.40 \times$ Block-holder $-34.86 \times$ Insiders $+0.004 \times$ fund_no

$-11.30 \times$ filing_13d $)))) \times \exp (-71.20 \times(-0.89 \times$ Stagger

$-2.19 \times$ Poison $-0.93 \times$ Merger $+36.72 \times$ Boardindep $+1.34 \times$ Bylaw

$-3.90 \times$ Charter $)+\ln \left(\mathrm{e}^{\wedge}(0.54 \times\right.$ institutional $-19.91 \times$ Block-holder

$+30.36 \times$ Insiders $-0.0011 \times$ fund_no $+11.899 \times$ filing_13d)

$+\mathrm{e}^{\wedge}(0.26 \times$ institutional $+22.40 \times$ Block-holder $-34.86 \times$ Insiders

$+0.004 \times$ fund_no $-11.30 \times$ filing_13d $))) / \exp (-71.20 \times(0.18 \times$ Stagger

$+2.62 \times$ Poison $+0.54 \times$ Merger $-28.96 \times$ Boardindep $-0.47 \times$ Bylaw

$+2.26 \times$ Charter $)+\exp (-71.20 \times(-0.89 \times$ Stagger $-2.19 \times$ Poison

$-0.93 \times$ Merger $+36.72 \times$ Boardindep $+1.34 \times$ Bylaw $-3.90 \times$ Charter)

$+\ln \left(\mathrm{e}^{\wedge}(0.54 \times\right.$ institutional $-19.91 \times$ Block-holder $+30.36 \times$ Insiders

$-0.0011 \times$ fund_no $+11.899 \times$ filing_13d $)+\mathrm{e}^{\wedge}(0.26 \times$ institutional

$+22.40 \times$ Block-holder $-34.86 \times$ Insiders $+0.004 \times$ fund no

$-11.30 \times$ filing_13d $))) \times \mathrm{e}^{\wedge}(0.26 \times$ institutional $+22.40 \times$ Block-holder

$-34.86 \times$ Insiders $+0.004 \times$ fund_no $-11.30 \times$ filing_13d $) /\left(\mathrm{e}^{\wedge}(0.54\right.$

$\times$ institutional $-19.91 \times$ Block-holder $+30.36 \times$ Insiders $-0.0011 \times$ fund_no

$+11.899 \times$ filing_13d $)+\mathrm{e}^{\wedge}(0.26 \times$ institutional $+22.40 \times$ Block-holder

$-34.86 \times$ Insiders $+0.004 \times$ fund_no $-11.30 \times$ filing_13d)) 


\section{Note: Definition of Variables}

TA: industry adjusted total asset (log).

HPR: market adjusted holding period returns.

FCF: industry adjusted free cash flow scaled by total asset.

Leverage: industry adjusted leverage ratio (square root).

MTB: industry adjusted market to book ratio (log).

Proposal: shareholder proposal submittal in prior year (square root).

Stagger: Indicator variable, staggered board.

Poison: Indicator variable, poison pills.

Merger: Indicator variable, super majority requirements to approve a merger.

Boardindep: board independence level.

Bylaw: Indicator variable, super majority requirements to amend bylaws.

Charter: Indicator variable, super majority requirements to amend company charter.

Institutional: Institutional ownership.

Block-holder: block-holder ownership.

Insiders: insider ownership.

Fund_no: number of funds

Filing_13d: indicator variable of active block-holders who file Schedule13-d with the SEC. 